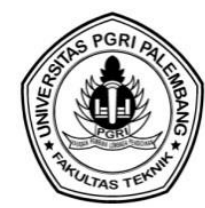

\title{
PENGARUH PENAMBAHAN LIMBAH SERBUK KAYU TERHADAP KUAT TEKAN PAVING BLOCK
}

\author{
Devi Meileni, Herri Purwanto*, Agus Setiobudi \\ Prodi Teknik Sipil, Fakultas Teknik, Universitas PGRI Palembang \\ *Corresponding Author, email: irwanto1969@gmail.com
}

\begin{abstract}
ABSTRAK
Rantau Alai adalah wilayah di Kabupaten Ogan Ilir yang salah satu usaha penduduknya banyak membuat perlengkapan rumah tangga, dan hasil olahannya menghasilkan limbah serbuk kayu yang tidak dimanfaatkan dan diperlukan alternatif untuk mengatasi limbah tersebut dan salah satunya untuk bahan campuran pembuatan paving block. Oleh karena itu, tujuan dari penelitian ini adalah untuk mengetahui seberapa besar pengaruh penambahan limbah serbuk kayu sebagai bahan campuran pembuatan paving block dengan variasi campuran 0\%, 5\%, 10\% dan 15\% melalui pengujian kuat tekan. Dalam penelitian ini akan melakukan pengujian sampel pada umur 7, 14 dan 28 hari dengan jumlah keseluruhan sampel sebanyak 60 paving block dengan variasi penambahan limbah serbuk kayu 0\%, 5\%, 10\% dan 15\% sebanyak 15 paving block untuk setiap variasinya. Dari hasil penelitian kuat tekan tertinggi dibanding dengan kondisi normal terjadi pada penambahan limbah serbuk kayu sebesar 10\%, yaitu pada umur 7 hari dengan kuat tekan 78,38 kg/ $\mathrm{cm}^{2}(26,91 \%)$, umur 14 hari kuat tekan 82,24 kg/ $\mathrm{cm}^{2}(12,49 \%)$, umur 28 hari kuat tekan $127,68 \mathrm{~kg} / \mathrm{cm}^{2}$ (10,55\%). Sehingga penggunaan $10 \%$ limbah serbuk kayu daerah Rantau Alai sebagai campuran pada pembuatan paving block dapat meningkatkan kuat tekan sebesar 10,55\% dengan nilai kuat tekan $127,68 \mathrm{~kg} / \mathrm{cm}^{2}$
\end{abstract}

Kata Kunci : Rantau Alai, Limbah Serbuk Kayu, Paving Block, Kuat Tekan

\begin{abstract}
Rantau Alai is an area in Ogan Ilir Regency where one of the businesses of the population makes a lot of household equipment, and the processing results produce wood sawdust waste that is not used and an alternative is needed to overcome this waste and one of them is for a mixture of making paving blocks. Therefore, the aim of this study was to determine how much influence the addition of wood sawdust waste as a mixture for making paving blocks with a mixed variation of 0\%, 5\%, 10\% and 15\% through compressive strength testing. In this study, samples were tested at the age of 7, 14 and 28 days with a total sample size of 60 paving blocks with variations in the addition of wood sawdust waste 0\%, 5\%, 10\% and $15 \%$ of 15 paving blocks for each variation. From the results of the research, the highest compressive strength compared to normal conditions occurs in the addition of wood sawdust waste by $10 \%$, namely at the age of 7 days with a compressive strength of $78.38 \mathrm{~kg} / \mathrm{cm}^{2}(26.91 \%), 14$ days of age the compressive strength of $82.24 \mathrm{~kg} / \mathrm{cm}^{2}$ (12.49\%), 28 days old, compressive strength $127.68 \mathrm{~kg} / \mathrm{cm}^{2}$ (10.55\%). So that the use of $10 \%$ wood sawdust waste from the Rantau Alai area as a mixture in making paving blocks can increase the compressive strength by $10.55 \%$ with a compressive strength value of $127.68 \mathrm{~kg} / \mathrm{cm}^{2}$
\end{abstract}

Keywords : Rantau Alai, Wood Sawdust Waste, Paving Block, Compressive Strength

\section{PENDAHULUAN}

Pemanfaatan bahan sisa atau limbah untuk pembuatan produk telah banyak dikembangkan saat ini, antara lain limbah pertanian dan limbah industri. Ada banyak keuntungan menggunakan barang bekas ini, termasuk harga yang jauh lebih murah, yang dapat memberikan nilai tambah pada produk.

Daerah Rantau Alai Kabupaten Ogan Ilir merupakan salah satu daerah yang usaha penduduknya banyak membuat perlengkapan rumah tangga seperti kursi, lemari, tempat tidur dan lain sebagainya. Bahan utama pembuatan perlengkapan tersebut adalah kayu 
yang diambil dari panglong kayu di sekitar wilayah Rantau Alai. Dan dari hasil pengolahan tersebut banyak menghasilkan serbuk kayu yang tidak dimanfaatkan warga sekitar dan menjadi limbah yang tidak bermanfaat. Sehingga perlu suatu terobosan agar dapat memanfaatkan limbah serbuk kayu tersebut, salah satunya sebagai bahan campuran dalam pembuatan paving block atau conblock. Dimana proses pembuatan paving block dibutuhkan material campuran yang memiliki berat jenis rendah, sehingga limbah serbuk kayu sangat cocok sebagai salah satu bahan alternatif yang dapat digunakan, karena limbah serbuk kayu memiliki berat jenis yang rendah. Dalam pemanfaatan limbah serbuk kayu dalam pembuatan paving block, limbah serbuk kayu berfungsi untuk mengurangi penggunaan semen.

Paving block Paving slab adalah suatu komposisi bahan bangunan yang terbuat dari campuran semen portland, air dan agregat, dengan atau tanpa bahan tambahan lain yang tidak menurunkan mutu (Sebayang dkk, 2012). Paving block banyak digunakan pada perkerasan jalan, seperti trotoar, tempat parkir, jalan perumahan atau area perumahan, taman, dan lain sebagainya. Dengan paving block yang mudah dipasang dan dirawat, dan tersedia dalam berbagai bentuk dan warna, yang sangat populer di kalangan konsumen. Paving block merupakan metode alternatif untuk menutupi atau mengeraskan permukaan tanah dan merupakan perkerasan semi lentur. Paving block juga dikenal dengan sebutan bata beton (concrete block) atau conblock. Menurut SNI-03-0691-1996 (dalam Iriawan, 2012), paving block (bata beton untuk lantai) adalah komposisi bahan bangunan yang dibuat dari pencampuran semen dan agregat dengan atau tanpa bahan tambahan lain, tetapi tidak mengurangi mutu bata beton. Selain berfungsi sebagai penutup permukaan suatu areal tanah dan juga sebagai tempat peresapan air, paving block bisa menjadi alternatif untuk lapisan perkerasan, dimana kekuatan paving block ditentukan oleh kuat tekan masing-masing elemen dan gesekan antar elemen paving block. Pemanfaatan paving block umumnya digunakan di rumah, kantor, tempat parkir dan lansekap. Karena pemasangannya tidak memerlukan banyak peralatan, dan produksi massal dimungkinkan, maka paving block menjadi salah satu alternatif yang sering digunakan sebagai pelengkap dalam pekerjaan sarana dan prasarana suatu proyek. Selain mampu menahan beban statis, dinamis, dan impak, paving block juga dapat menahan panas dari mesin kendaraan. Oleh karena itu, hal ini membuat permintaan akan paving block sebagai pengganti jalan berbeban ringan semakin meningkat (Helmahera dkk, 2016). Standar mutu yang harus dipenuhi paving block untuk lantai menurut SNI 03-0691-1996 adalah : (1) Penampilan paving block harus memiliki bentuk yang sempurna, tanpa retak dan cacat, sudut dan rusuk tidak mudah dirapikan dengan kekuatan jari, (2) Bentuk dan ukuran paving block tergantung pada kesepakatan antara pengguna dan pabrikan. Berbagai produsen telah menulis deskripsi tentang bentuk, ukuran, struktur, dan lain-lain dari lantai beraspal di selebaran (leaflet), (3) Penyimpangan yang diijinkan dari ketebalan perkerasan lantai adalah sekitar $3 \mathrm{~mm}$. Keuntungan menggunakan paving block (Ariansyah, 2020) yaitu : (1) pelaksanaannya mudah dan tidak perlu keahlian khusus, (2) dapat diproduksi secara massal, (3) Perawatannya sederhana dan biayanya murah, karena jika salah satu paving block yang rusak dapat dipasang kembali setelah dibongkar, (4) Tahan terhadap beban vertikal dan horizontal, (5) Dapat meminimalkan limpasan dan meningkatkan penetrasi tanah, dikarenakan pemasangannya yang mempunyai celah untuk 
air masuk ke tanah, (6) Pemasangannya tidak menimbulkan kebisingan, (7) Memiliki nilai estetika yang unik, jika perangkat didesain dengan bentuk dan warna yang berbeda.

Menurut Maulana (2018), paving block diklasifikasikan berdasarkan bentuk, tebal, kekuatan, dan warna, sebagai berikut : (1) berdasarkan bentuk terbagi atas dua macam, yaitu segi empat dan segi banyak, (2) berdasarkan ketebalan terbagi menjadi tiga macam yaitu ketebalan $60 \mathrm{~mm}$ (untuk beban lalu lintas ringan), ketebalan $80 \mathrm{~mm}$ (untuk beban lalulintas sedang sampai berat), dan ketebalan $100 \mathrm{~mm}$ (untuk beban lalu lintas super berat), tetapi tetap diperhatikan kuat tekannya, (3) berdasarkan kekuatan, yaitu mutu I (f'c 34 - $40 \mathrm{Mpa}$ ), mutu II (f'c 25,5 - $30 \mathrm{Mpa}$ ), mutu III (f'c 17 - $20 \mathrm{MPa}$ ), (4) Berdasarkan warna yaitu abu-abu, hitam dan merah, di mana paving block berwarna tidak hanya meningkatkan estetika, tetapi juga dapat digunakan untuk memberikan batasan, seperti tempat parkir dan sebagainya. Widari (2015), dalam penelitiannya menggunakan suhu tungku $800{ }^{\circ} \mathrm{C}$ untuk membakar limbah serbuk gergaji merbau. Abu hasil pembakaran kemudian diayak melalui saringan No. 200. Benda uji dibuat dengan cara dicetak menggunakan alat vibratory press, penambahan serbuk gergaji 10\%, 15\%, 20\%, dan $25 \%$, serta perendaman selama 28 hari. Kuat tekan rata-rata hasil pengujian pervariasinya adalah 11,979 Mpa, 13,281 Mpa, 14,792 Mpa dan 13,594 Mpa. Dan daya serap airnya sebesar 4,345\%, 3,529\%, 2,555\% dan 3,063\%. Dan hasil kesimpulan dari penelitiannya menyatakan bahwa paving block setelah ditambahkan serbuk gergaji kayu merbau, kuat tekannya menjadi lebih rendah dibandingkan dengan paving block biasa (normal), yaitu $17.760 \mathrm{Mpa}$, yang termasuk paving block golongan kualitas $\mathrm{C}$ dan hanya dapat digunakan untuk pejalan kaki. Oleh karena itu, perlu dilakukan penelitian lebih lanjut pada jenis kayu lain untuk mendapatkan kualitas paving block yang lebih baik. Ahmad (2020), Pada penelitian yang menggunakan serbuk penggergajian kayu yang diambil dari usaha mebel di Lombok, Nusa Tenggara Barat, dengan komposisi serbuk gergaji bervariasi dari $0 \%, 5 \%, 10 \%, 15 \%$, dan $20 \%$. Hasil pengujian mendapatkan nilai yang berbeda untuk setiap paving block yaitu dari perbandingan 0\%; 5\%; 10\%; $15 \%$ dan 20\% adalah 11,59MPa; 6,42 MPa; 6,00 MPa; 5,25 MPa dan 5,08 MPa. Nilai kuat tarik belah $0 \%, 5 \%, 10 \%, 15 \%$ dan $20 \%$ berturut-turut adalah $0,889 \mathrm{MPa}, 0,121 \mathrm{MPa}, 0,425 \mathrm{MPa}$, 0,584 MPa dan 0,425 MPa, dengan nilai kuat tarik belah maksimum 0,889 $\mathrm{MPa} 0 \%$.

Kayu adalah bahan yang didapat dari hasil penebangan pohon di hutan. Tanaman kayu diklasifikasikan dalam dua kelompok yaitu Gymnospora (Softwood) dan Angiospora yang dikenal dengan Hardwood (Windyasari dalam Oktavia, 2014). Hasil dari pengolahan kayu akan menghasilkan limbah dan perlu penanganan yang baik, dan menurut Billah (2009), dalam penanganan limbah serbuk gergaji kayu bila dibiarkan akan membusuk, tetapi bila ditumpuk kemudian dibakar juga akan bermasalah dan kesemuanya berdampak negatif terhadap lingkungan sekitar. Sehingga limbah serbuk kayu tersebut akan sangat berguna apabila bisa dimanfaatkan semaksimal mungkin dan salah satunya sebagai bahan campuran pembuatan paving block, tetapi perlu dikaji lebih lanjut seberapa efektif limbah serbuk kayu tersebut bisa digunakan sebagai bahan tambahnya. Oleh karena itu, tujuan dari penelitian ini adalah untuk mengetahui seberapa besar pengaruh penambahan limbah serbuk kayu sebagai bahan campuran pembuatan paving block dengan variasi campuran $0 \%, 5 \%, 10 \%$ dan $15 \%$ melalui pengujian kuat tekan. 


\section{METODE PENELITIAN}

Penelitian ini dilakukan di Laboratorium PT. Graha Tekindo Utama Cabang Palembang yang bertujuan untuk mengetahui pengaruh pemanfaatan bahan limbah serbuk kayu sebagai bahan tambah pembuatan paving block dengan variasi penambahan limbah serbuk kayu dengan kondisi 0\%, 5\%, 10\% dan 15\%. Pengujian kuat tekan paving block dilakukan pada umur 7 hari, 14 hari dan 28 hari dengan total benda uji sebanyak 60 sempel, dimana masing-masing umur pengujian dan persentase campuran dibuat 5 sampel

Material yang digunakan yaitu semen Baturaja tipe I, agregat halus berupa pasir dari Tanjung Raja Ogan Ilir, air dari PDAM PT. Graha Tekindo Utama dan limbah serbuk kayu dari daerah Rantau Alai, Tanjung Raja Ogan Ilir
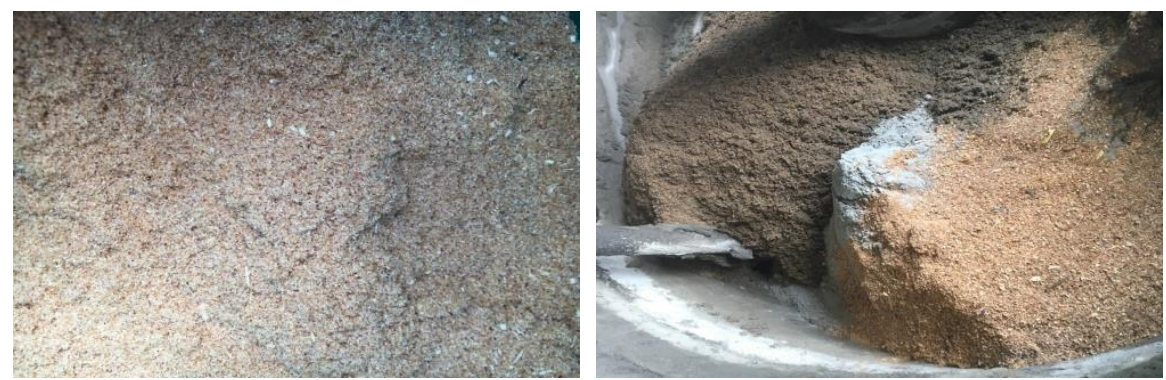

Gambar 1. Material Serbuk Kayu dan Bahan Pembuatan Paving Block

\section{HASIL DAN PEMBAHASAN}

Dari hasil pengujian kuat tekan paving block yang dilakukan pada umur 7 hari, 14 hari dan 28 hari dengan variasi penambahan limbah serbuk kayu 0\%, 5\% dan 10\% dan $15 \%$ didapat hasil sebagai berikut :

1. Kuat tekan umur 7 hari

Hasil pengujian pada umur 7 hari dapat dilihat dari tabel dan gambar berikut :

Tabel 1. Hasil Persentase Kuat Tekan Umur 7 Hari

\begin{tabular}{|c|l|c|c|}
\hline No & \multicolumn{1}{|c|}{$\begin{array}{c}\text { Variasi Campuran } \\
\text { Penambahan }\end{array}$} & $\begin{array}{c}\text { Kuat tekan } \\
\left(\mathrm{Kg} / \mathrm{Cm}^{2}\right)\end{array}$ & $\begin{array}{c}\text { Peningkatan } \\
\text { kekuatan }(\%)\end{array}$ \\
\hline 1 & Limbah Serbuk Kayu (SK) 0\% & 61,76 & 0,00 \\
\hline 2 & Limbah Serbuk Kayu (SK) 5\% & 67,50 & 9,29 \\
\hline 3 & Limbah Serbuk Kayu (SK) 10\% & 78,38 & 26.91 \\
\hline 4 & Limbah Serbuk Kayu (SK) 15\% & 63,24 & 2,40 \\
\hline
\end{tabular}




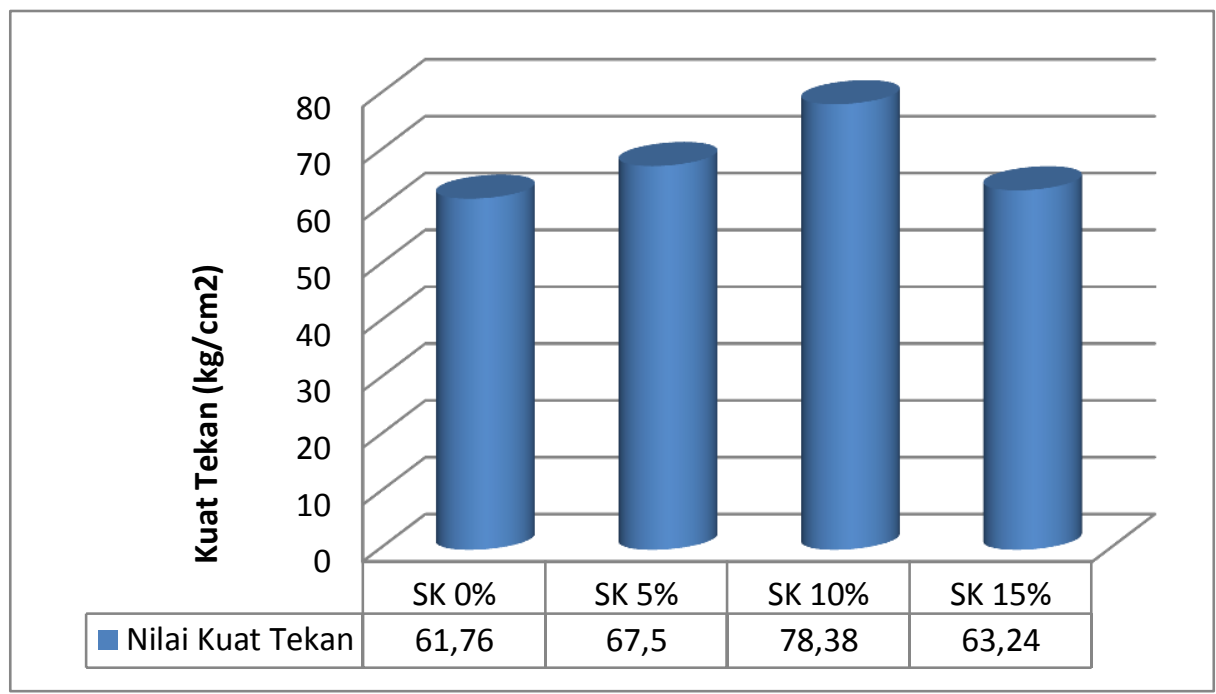

Gambar 2. Kuat Tekan Paving Block Umur 7 Hari

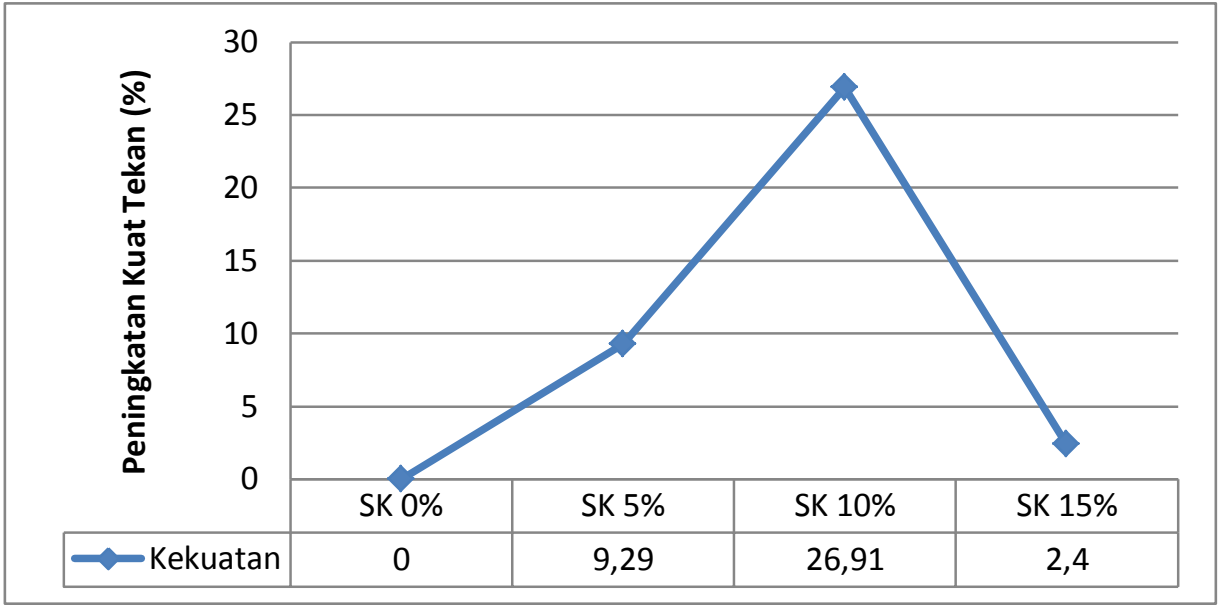

Gambar 3. Peningkatan Kekuatan Paving Block Umur 7 Hari

Dari tabel diatas hasil uji kuat tekan paving block nilai maksimum kuat tekan pada umur 7 hari terjadi pada variasi paving block dengan campuran penambahan limbah serbuk kayu $10 \%$, dengan nilai kuat tekan karakteristik $78,38 \mathrm{~kg} / \mathrm{cm}^{2}$ dan nilai peningkatan kekuatan dari sampel normal sebesar 26,91\%.

2. Kuat tekan umur 14 hari

Hasil pengujian pada umur 14 hari dapat dilihat dari tabel dan gambar berikut :

Tabel 2. Hasil Persentase Kuat Tekan Umur 14 Hari

\begin{tabular}{|c|l|c|c|}
\hline No & $\begin{array}{c}\text { Variasi Campuran } \\
\text { Penambahan }\end{array}$ & $\begin{array}{c}\text { Kuat tekan } \\
\left(\mathrm{Kg} / \mathrm{Cm}^{2}\right)\end{array}$ & $\begin{array}{c}\text { Peningkatan } \\
\text { kekuatan }(\%)\end{array}$ \\
\hline 1 & Limbah Serbuk Kayu (SK) 0\% & 73,11 & 0,00 \\
\hline 2 & Limbah Serbuk Kayu (SK) 5\% & 70,66 & -3.35 \\
\hline 3 & Limbah Serbuk Kayu (SK) 10\% & 82,24 & 12.49 \\
\hline 4 & Limbah Serbuk Kayu (SK) 15\% & 68,29 & $-6,59$ \\
\hline
\end{tabular}




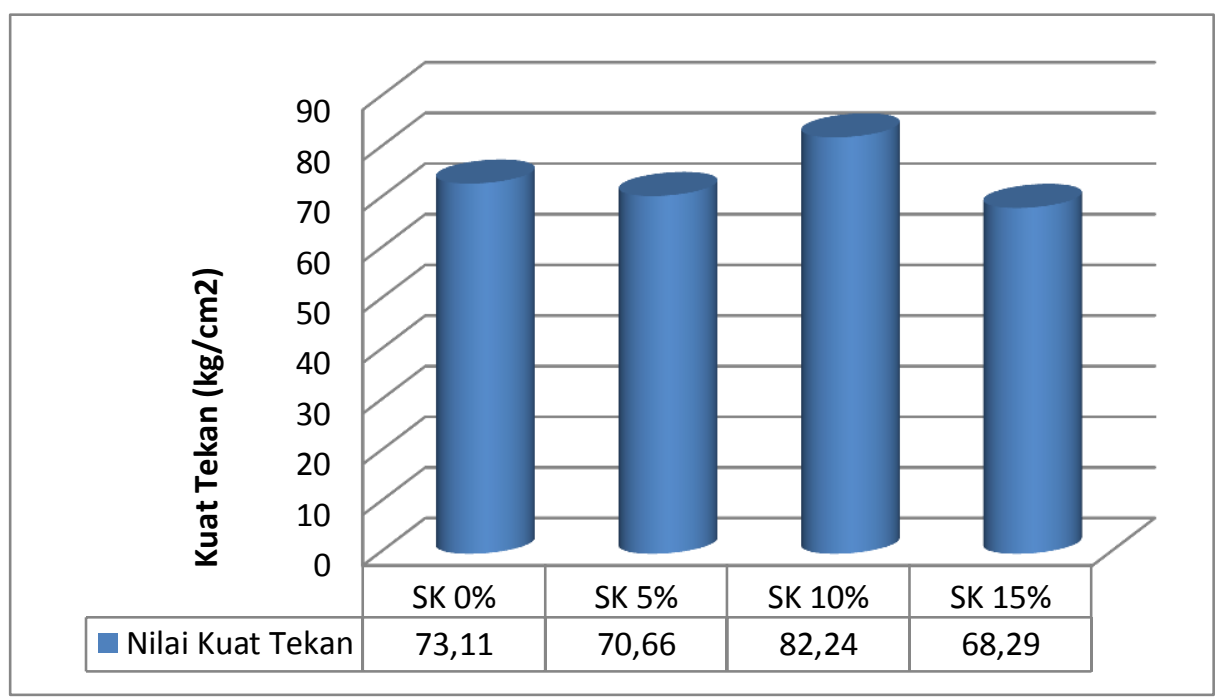

Gambar 4. Kuat Tekan Paving Block Umur 14 Hari

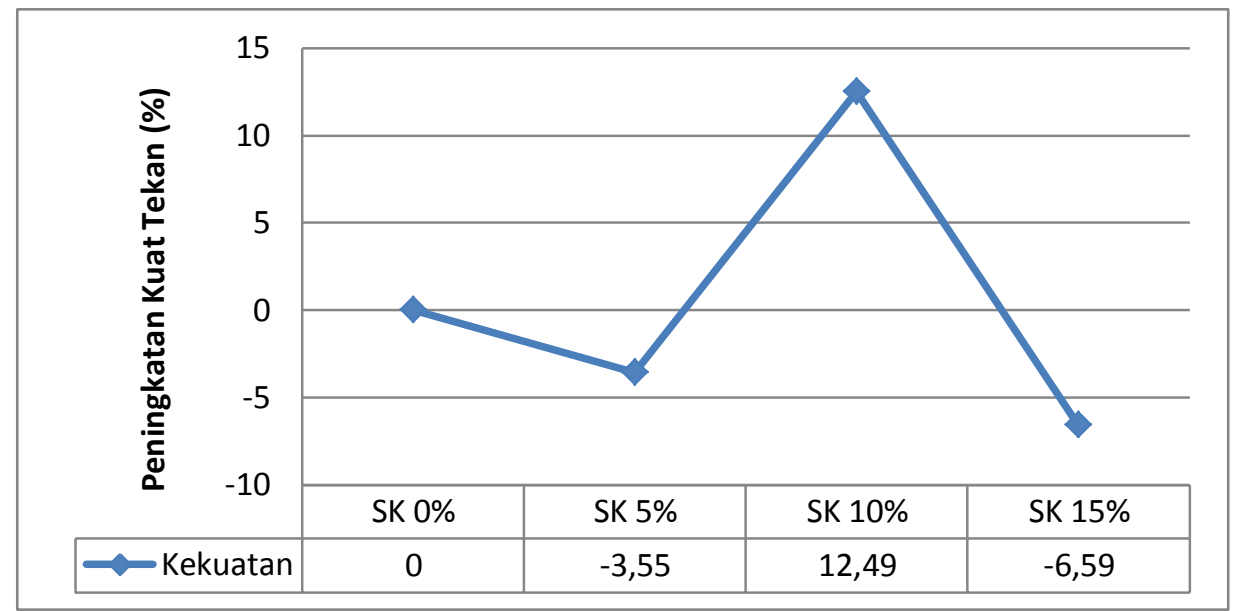

Gambar 5. Peningkatan Kekuatan Paving Block Umur 14 Hari

Dari tabel diatas hasil uji kuat tekan paving block nilai maksimum kuat tekan pada umur 14 hari terjadi pada variasi paving block dengan campuran penambahan limbah serbuk kayu $10 \%$, dengan nilai kuat tekan karakteristik $82,24 \mathrm{~kg} / \mathrm{cm}^{2}$ dan nilai peningkatan kekuatan dari sampel normal sebesar $12,49 \%$.

3. Kuat tekan umur 28 hari

Hasil pengujian pada umur 28 hari dapat dilihat dari tabel dan gambar berikut : Tabel 3. Hasil Persentase Kuat Tekan Umur 28 Hari

\begin{tabular}{|c|l|c|c|}
\hline No & \multicolumn{1}{|c|}{$\begin{array}{c}\text { Variasi Campuran } \\
\text { Penambahan }\end{array}$} & $\begin{array}{c}\text { Kuat tekan } \\
\left(\mathrm{Kg} / \mathrm{Cm}^{2}\right)\end{array}$ & $\begin{array}{c}\text { Peningkatan } \\
\text { kekuatan }(\%)\end{array}$ \\
\hline 1 & Limbah Serbuk Kayu (SK) 0\% & 115,50 & 0,00 \\
\hline 2 & Limbah Serbuk Kayu (SK) 5\% & 119,06 & 3.08 \\
\hline 3 & Limbah Serbuk Kayu (SK) 10\% & 127.68 & 10,55 \\
\hline 4 & Limbah Serbuk Kayu (SK) 15\% & 112,83 & $-2,31$ \\
\hline
\end{tabular}




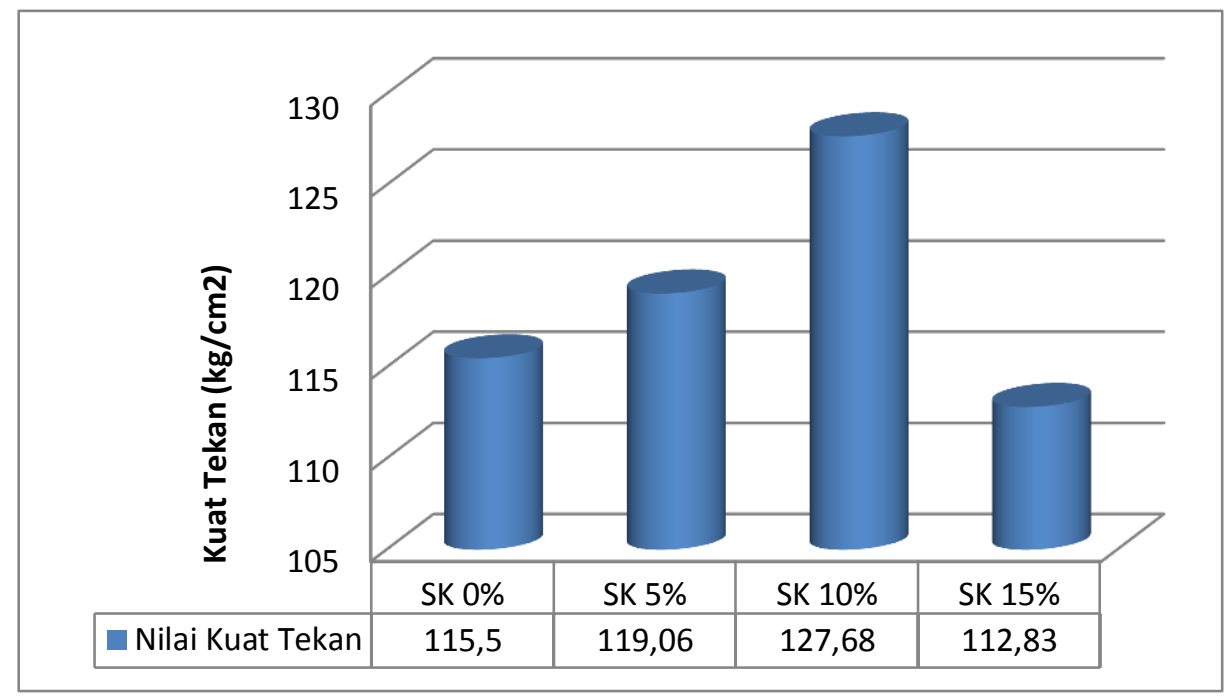

Gambar 6. Kuat Tekan Paving Block Umur 28 Hari

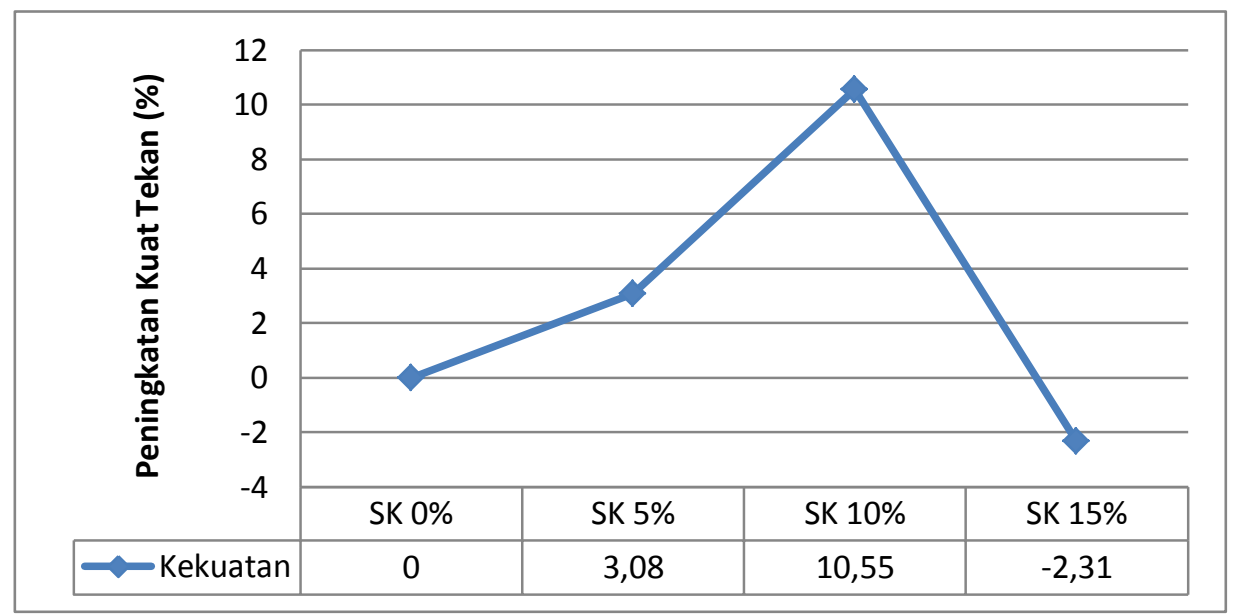

Gambar 7. Peningkatan Kekuatan Paving Block Umur 28 Hari

Dari tabel diatas hasil uji kuat tekan paving block nilai maksimum kuat tekan pada umur 28 hari terjadi pada variasi paving block dengan campuran penambahan limbah serbuk kayu $10 \%$, dengan nilai kuat tekan karakteristik $127,68 \mathrm{~kg} / \mathrm{cm}^{2}$ dan nilai peningkatan kekuatan dari sampel normal sebesar 10,55\%.

Dari hasil pengujian kuat tekan pada paving block dengan campuran penambahan limbah serbuk kayu 5\%,10\% dan 15\% dan bila dibandingkan dengan paving block tanpa campuran limbah serbuk kayu (normal), pada umur 28 hari terjadi peningkatan kuat tekan untuk campuran penambahan limbah serbuk kayu $10 \%$ yaitu 10,55\% dengan kuat tekan $127,68 \mathrm{~kg} / \mathrm{cm}^{2}$. Sedangkan paving block normal pada umur 28 hari kuat tekannya 115,50 $\mathrm{kg} / \mathrm{cm}^{2}$. Jadi dapat disimpulkan bahwa penggunaan $10 \%$ limbah serbuk kayu daerah Rantau Alai sebagai campuran pada pembuatan paving block dapat meningkatkan kuat tekan sebesar 10,55\% dengan nilai kuat tekan $127,68 \mathrm{~kg} / \mathrm{cm}^{2}$. Dan bila dibandingkan dengan penelitian terdahulu dari Widari (2015) dengan menggunakan serbuk kayu Merbau yang dibakar, kuat tekan tertinggi terjadi dikomposisi $20 \%$ serbuk kayu dengan nilai $14,792 \mathrm{Mpa}\left(150,38 \mathrm{~kg} / \mathrm{cm}^{2}\right)$ 


\section{KESIMPULAN}

Dari hasil penelitian dan pengujian kuat tekan paving block yang dilakukan, dapat disimpulkan sebagai berikut :

1. Pembuatan paving block dengan penambahan limbah serbuk kayu (SK) $5 \%$ pada umur 7 hari menghasilkan kuat tekan $67,50 \mathrm{~kg} / \mathrm{cm}^{2}$, umur 14 hari $70,66 \mathrm{~kg} / \mathrm{cm}^{2}$, umur 28 hari 119,06 kg/ $\mathrm{cm}^{2}$. Dengan persentase peningkatan kekuatan 9,29\%, -3,35\% dan $3,08 \%$ dibandingkan dengan paving block normal $(0 \%)$ yaitu $61,76 \mathrm{~kg} / \mathrm{cm}^{2}$

2. Pembuatan paving block dengan penambahan limbah serbuk kayu (SK) $10 \%$ pada umur 7 hari menghasilkan kuat tekan 78,38 kg/cm ${ }^{2}$, umur 14 hari $82,24 \mathrm{~kg} / \mathrm{cm}^{2}$, umur 28 hari $127,68 \mathrm{~kg} / \mathrm{cm}^{2}$. Dengan persentase peningkatan kekuatan $26,91 \%, 12,49 \%$ dan $10,55 \%$ dibandingkan dengan paving block normal $(0 \%)$ yaitu $73,11 \mathrm{~kg} / \mathrm{cm}^{2}$

3. Pembuatan paving block dengan penambahan limbah serbuk kayu (SK) $15 \%$ pada umur 7 hari menghasilkan kuat tekan $63,24 \mathrm{~kg} / \mathrm{cm}^{2}$, umur 14 hari $68,29 \mathrm{~kg} / \mathrm{cm}^{2}$, umur 28 hari $112,83 \mathrm{~kg} / \mathrm{cm}^{2}$. Dengan persentase peningkatan kekuatan 2,40\%, -6,59\% dan $2,31 \%$ dibandingkan dengan paving block normal $(0 \%)$ yaitu $115,50 \mathrm{~kg} / \mathrm{cm}^{2}$

4. Kuat tekan tertinggi terdapat pada pembuatan paving slab dengan limbah serbuk kayu (SK) 10\%. Kuat tekan umur 28 hari sebesar 127,68 kg/cm2, dan kuat tekannya meningkat sebesar 10,55\% dari paving block normal ( $0 \%$, tidak ada limbah serbuk gergaji yang ditambahkan)

5. Menggunakan $10 \%$ limbah serbuk kayu daerah Rantau Alai sebagai campuran pada pembuatan paving block, bila dibandingkan dengan paving block biasa (0\%) yaitu $115,50 \mathrm{~kg} / \mathrm{cm} 2$, kuat tekannya dapat ditingkatkan sebesar $10,55 \%$, dengan nilai kuat tekan $127,68 \mathrm{~kg}$

\section{DAFTAR PUSTAKA}

Ahmad, Z. (2020). Pemanfaatan Serbuk Gergaji Kayu Sebagai Bahan Pengganti Sebagian Pasir Dalam Pembuatan Paving Block (Doctoral dissertation, Universitas_Muhammadiyah_Mataram).

Ariansyah, A. (2020). Studi Pemanfaatan Limbah Plastik Sebagai Bahan Utama Pembuatan Paving Block (Doctoral dissertation, Universitas Muhammadiyah Mataram).

Billah, M. (2009). Bahan Bakar Alternatif Padat (BBAP) Serbuk Gergaji Kayu. UPN Pres

Helmahera, M., Setyanto, S., \& Adha, I. (2016). Pengaruh Waktu Pemeraman Terhadap Uji Kuat Tekan Paving Blok Menggunakan Campuran Tanah dan Kapur dengan Alat Pemadatan Modifikasi. Jurnal Rekayasa Sipil dan Desain, 4(1), 127-136.

Iriawan, I. (2012). Pengaruh penambahan terak terhadap kuat tekan paving block. (Skripsi, UNS).

Maulana, I. (2018). Perbedaan Kuat Tekan Paving Block dengan Metode Pembuatan Manual, Mesin Pres Hidrolis dan Mesin Pres Hidrolis Vibrasi. 
Oktavia Sitorus, D. (2014). Peningkatan Potensi Campuran Serat Sabut Kelapa dan Serbuk Kayu Gergaji Terkativasi H2SO4 Sebagai Media Adsorben Zat Warna Terhadap Limbah Kain Songket (Doctoral dissertation, Politeknik Negeri Sriwijaya).

Sebayang, S., Diana, I. W., \& Purba, A. (2012). Perbandingan mutu paving block produksi manual dengan produksi masinal. Rekayasa: Jurnal Ilmiah Fakultas Teknik Universitas Lampung, 15(2), 139-150.

SNI 03-0691,1996. Bata beton (ppaving block) Badan Standardisasi Nasional

Widari, L. A. (2015). Pengaruh Penggunaan Abu Serbuk Kayu Terhadap Kuat Tekan Dan Daya Serap Air Pada Paving Block. Teras Jurnal-Jurnal Teknik Sipil, 5(1). 